\title{
Assessment of plant growth-promoting stress-tolerant endophytes screened from Bougainvillea glabra for the growth of Triticum aestivum $\mathrm{L}$. and Zea mays
}

\author{
ARUN KARNWAL * \\ Department of Microbiology, School of Bioengineering and Biosciences, Lovely Professional University, Phagwara, India
}

\begin{abstract}
Globally, more than 5.2 billion hectares of farming fields are damaged through erosion, salinity, and soil deterioration. Salt stress-tolerant bacteria have plant growth-promoting (PGP) characteristics that can be used to overcome environmental stresses. Isolation and screening of salt-tolerant endophytes from Bougainvillea glabrawere achieved through surface sterilization of leaves, followed by their cultivation on $0.5 \% \mathrm{NaCl}$-supplemented media. The performance of isolates for indole acetic acid (IAA) production, phosphate solubilization, ACC deaminase activity, ammonia production, siderophore production, and stress tolerance was determined. In the present study, 5 morphologically distinct salt-tolerant endophytic bacteria were cultured. Out of 5 isolates, 60\% salt-tolerant endophytes showed phosphate solubilization, 100\% IAA production, 40\% ACC-deaminase activity, 100\% siderophore production, $40 \%$ ammonia production and $60 \% \mathrm{HCN}$ production. Dendrogram generated based on stress tolerance showed three clusters: clusters 1 and 2 containing two isolates and cluster 3 containing 1 isolate. Based on the highest PGP activities, BoGl17 and BoGl21 isolates were chosen and further tested for wheat and corn growth promotion. The isolates increased wheat shoot and root dry weight by $40 \%$ and $80 \%$, and by $69 \%$ and $126 \%$ for BoGl17 and BoGl21, respectively. The bacterial isolates identified as Pseudomonas reidholzensis BoGl17 had 95.59\% identity with Pseudomonas reidholzensis strain ID3, while the isolate Bacillus aerius BoGl21 had 90.96\% identity with Bacillus aerius strain $24 \mathrm{~K}$ based on phenotypic features and $16 \mathrm{~S}$ rRNA gene sequencing results. Both isolates significantly improved plant growth as compared to uninoculated plants.
\end{abstract}

Key words: bacterial endophyte; dendrogram; molecular analysis; plant growth development; salinity tolerance

\section{Introduction}

Securing food availability for the world population is one of the significant challenges for the present agricultural system (FAO, 2009). All living forms on earth are purely dependent on plants as they fulfill their various primary needs, i.e., oxygen and staple food (Macauley, 2015). It has been shown (FAO, 2009; Macauley, 2015 ) that more than $90 \%$ of global nutrition fulfillment is achieved by 12 crop varieties and 14 animal varieties. Of these 12 dominant plant species, crops such as wheat, rice, and corn are primary energy-providing crops for more than $50 \%$ of the world's population (Myresiotis et al., 2015). In the natural habitat, plants share a considerable amount of space and nutrients with many na- turally available microorganisms. This nutrient-rich root neighboring habitat is highly promotive for initiating positive mutualistic interactions between plants and microorganisms (Sarkar et al., 2018).

In the natural system, abiotic stresses, i.e., drought and salinity, limit and work as a significant constraint for the growth, yield, and quality of crops. Microbial inoculants refer to formulations composed of beneficial microorganisms that play an important role in soil ecosystems for sustainable agriculture. Microbial inoculants are environmentally friendly and are a potential alternative to chemical fertilizers and pesticides (Vejan et al., 2016; Etesami and Maheshwari, 2018). These organisms create a positive environment that can help in stress

\footnotetext{
* Corresponding author: Department of Microbiology, School of Bioengineering and Biosciences, Lovely Professional University, Phagwara, India; e-mail: arunkarnwal@gmail.com
} 
management. Plant growth-promoting bacteria (PGPB) can enhance plant growth and protect plants from diseases and abiotic stresses through a wide variety of mechanisms, including deaminase activity, nodule formation, siderophore production, organic acid production, and other physiological activities that help the plants to tolerate stress (Ullah et al., 2019). Several researchers (Tak et al., 2013; Kumar and Verma, 2018) have reported that the efficacy of plant growth-promoting rhizobacteria (PGPR) reduces under sudden changes of environmental conditions and they fail to respond in the field due to stress conditions. Therefore, selection for suitable stress-resistant species has become an essential parameter during the screening of microbial isolates suitable for the production of microbial inoculants (Karnwal and Dohroo, 2018). Salt stress in fields resulted in a significant decline of crop production for salt-susceptible and salt stress-tolerant plants. It has been noted that the majority of crops have low salt stress tolerance, i.e., salinity tolerance for wheat and corn is up to 6 and $2 \mathrm{dS} / \mathrm{m}$ (deciSiemens per meter), respectively (Shrivastava and Kumar, 2015). In the field where the salinity increases to $100 \mathrm{mM} \mathrm{NaCl}$ (approximately $10 \mathrm{dS} / \mathrm{m}$ ), rice (Oryza sativa) will die before maturity, while wheat will produce a reduced yield. Even barley (Hordeum vulgare), the most salt-tolerant cereal dies after extended period of growth at salt concentrations higher than $250 \mathrm{mM} \mathrm{NaCl}$ (equivalent to $50 \%$ seawater) (Shrivastava and Kumar, 2015). Earlier studies have demonstrated the beneficial role of microorganisms in alleviating salinity stress in crops and increasing product yield (Gulati et al., 2008; Passari et al., 2016; Abedinzadeh et al., 2019).

PGPB may be free-living bacteria, in symbiotic associations with plants, or as endophytic bacteria in host tissues (Glick, 1995; Glick and Bashan, 1997). PGPB may promote plant growth through direct or indirect mechanisms. The direct mechanism of promoting plant growth includes the production of phytohormones, siderophores, Hydrogen Cyanide (HCN), ACC deaminase, and ammonia; phosphate solubilization; decomposition of organic materials for smooth absorption; and $\mathrm{N}$ fixation. As indirect mechanisms, these bacteria decrease the effect of phytopathogenic microorganisms by increasing the immunity of host plants to resist phytopathogens (Yadav et al., 2011; Kumar et al., 2012; Karnwal, 2017).
In the present investigation, screening, characterization, and determination of PGP activities of salinity stress-tolerant bacteria isolated from Bougainvillea glabra were performed for the world's primarily staple crops-wheat and corn.

\section{Materials and methods}

\section{Isolation of bacterial endophytes}

The present study was conducted with endophytic culturable bacteria isolated from B. glabra growing at Bhojia Institute of Life Sciences, Budh, Baddi, Himachal Pradesh, India, located near the latitude 30.952802 and longitude 76.776914. Leaf samples were collected from healthy plants in sterilized Ziploc bags and sent to Microbiology Laboratory, Bhojia Institute of Life Sciences. The samples were washed with distilled water three times to remove adhering soil and other chemicals. Surface sterilization of the leaves was carried out by dipping in $75 \%$ ethanol for $30 \mathrm{~s}$ followed by treatment with $0.2 \% \mathrm{HgCl}_{2}$ for $3 \mathrm{~min}$ (Karnwal, 2009).

Surface-sterilized leaves were washed with sterilized distilled water five times to remove any residue of surface sterilizing chemicals, and aseptically shredded $\left(0.5 \mathrm{~cm}^{2}\right.$ size) leaf pieces were then placed on nutrient agar medium (NAM) supplemented with $4 \% \mathrm{NaCl}$. These plates were incubated for up to $72 \mathrm{~h}$ at $28 \pm 1^{\circ} \mathrm{C}$ in a dark area. The plates were inspected at 12 -h intervals for any bacterial growth. Individual bacterial colonies developing around the inoculated leaf parts were chosen depending on their macroscopic and microscopic characteristics and appearance. Pure cultures were established and then subsequently preserved under $30 \%$ glycerol for further studies.

\section{Screening for PGP traits}

\section{Solubilization of phosphate}

Phosphate solubilization assay was conducted by applying spot inoculation of each bacterial isolate on modified Pikovskaya's agar (HiMedia) (Gupta et al., 1994). The plates were incubated in an incubator for $48 \mathrm{~h}$ at $28 \pm 1^{\circ} \mathrm{C}$. The developments of clear zones around the colonies indicated phosphate solubilizing activity. Zones of solubilization were observed around the colonies, and the diameters of these zones were measured by applying the following equation of Edi-Premono et al. (1996). 
Phosphate solubilization index $(\mathrm{SI})=$

$$
=\frac{\text { (colony diameter }+ \text { halo zone diameter })}{\text { colony diameter }}
$$

The qualitative examination of liquefaction capability of inorganic phosphate by bacterial isolates was performed in vitro with Pikovskaya's broth by calculating existing liquid phosphate in the $0.5 \%$ tri-calcium phosphate (TCP) supplemented media. The broth was inoculated in triplicates with the isolated salt-tolerant bacteria. All flasks were incubated at $28 \pm 1^{\circ} \mathrm{C}$ in a rotary shaker incubator for $120 \mathrm{~h}$ at $180 \mathrm{rpm}$ and then centrifuged for $10 \mathrm{~min}$ at $11180 \mathrm{~g}$. The phosphate available in the culture medium was measured using the phosphomolybdate method (Watanabe and Olsen, 1965). During the experiment, at regular intervals, the $\mathrm{pH}$ of the broth was also measured using a Systronics-304 pH meter (Vaishnav et al., 2016).

\section{IAA-like auxin production}

IAA production was measured on DF (Dworkin and Foster) medium (Dworkin and Foster, 1958) enriched with $0.1 \%$ L-tryptophan and Salkowski reagent (2\% $0.5 \mathrm{FeCl}_{3}$ in $35 \% \mathrm{HClO}_{4}$ ) by using Salkowski's method (Armada et al., 2016). The bacterial isolates $(100 \mu \mathrm{l})$ were incubated in DF medium supplemented with L-tryptophan $(10 \mathrm{~g} / \mathrm{l})$ for $48 \mathrm{~h}$ at $28 \pm 1^{\circ} \mathrm{C}$. The culture broth was centrifuged at $11963 g$ in a cooling centrifuge, and $1 \mathrm{ml}$ of the culture supernatant was incubated with $2 \mathrm{ml}$ of Salkowski reagent in a test tube (Karnwal and Dohroo, 2018). This mixture was left without any disturbance in the dark at room temperature for $30 \mathrm{~min}$. The optical density (OD) was recorded at $530 \mathrm{~nm}$, and the amount of IAA-like auxins was determined as $\mu \mathrm{g} / \mathrm{ml}$ against the uninoculated control.

\section{ACC deaminase activity}

ACC (1-aminocyclopropane-1-carboxylate) deaminase activity for salt-tolerant isolates was analyzed on ACC (3 mM)-supplemented DF salts minimal medium (Dworkin and Foster, 1958) as a sole nitrogen source. The DF agar plates were inoculated with the bacterial cultures and incubated at $28 \pm 1^{\circ} \mathrm{C}$. The plates were observed for bacterial growth, and a positive result was noted after $48 \mathrm{~h}$.

\section{Siderophore production}

Chrome azurol S (CAS) medium was used to confirm the siderophore production potential of the bacterial isolates as described by Hemambika and Kannan (2012).
Bacterial culture after $24 \mathrm{~h}$ incubation was inoculated on CAS agar and incubated for $48-72 \mathrm{~h}$ at $28 \pm 1^{\circ} \mathrm{C}$ (Hemambika and Kannan, 2012). The change in CAS color from blue to orange, indicating iron chelation, was observed as halos surrounding the bacterial colonies, which confirmed siderophore production.

\section{Ammonia production}

The potential of bacterial isolates for ammonia production was investigated by following the method of Nehra et al. (2016), i.e., inoculation of bacterial isolates on peptone medium. The bacterial-inoculated medium was incubated for $48 \mathrm{~h}$ at $28 \pm 1^{\circ} \mathrm{C}$. The medium was further supplemented with Nessler's reagent $(0.5 \mathrm{ml})$ in $2: 1$ ratio. The development of brown to yellow color indicated a positive result for ammonia production, while the uninoculated medium was used as a reference.

\section{HCN determination}

The capability of the bacterial isolates to produce HCN was tested as described by Akter et al. (2016) with few modifications. NAM supplemented with $4.4 \mathrm{~g} / 1 \mathrm{gly}-$ cine was streaked with the bacterial isolates. A sterile Whatman No. 1 filter paper (Millipore) saturated with picric acid solution $\left(2.5 \mathrm{~g}\right.$ of $\left(\mathrm{O}_{2} \mathrm{~N}\right)_{3} \mathrm{C}_{6} \mathrm{H}_{2} \mathrm{OH} ; 12.5 \mathrm{~g}$ of $\mathrm{NaCO}, 1000 \mathrm{ml}$ of distilled $\mathrm{H}_{2} \mathrm{O}$ ) was placed on the upper lid of the Petri plate. Parafilm-sealed Petri plates were then incubated at $28 \pm 1^{\circ} \mathrm{C}$ until the development of light/moderate/intense brown color as a positive result for $\mathrm{HCN}$ production.

\section{Stress tolerance screening}

Salt stress tolerance potential of the bacterial isolates was investigated on NAM supplemented with different concentrations of $\mathrm{NaCl}$, i.e., $5 \%(0.86 \mathrm{M}) ; 7 \%(1.2 \mathrm{M})$; $8.5 \%(1.46 \mathrm{M}) ; 10 \%(1.71 \mathrm{M})$; and $12 \%$ (2.054 M). These plates were streaked with bacterial cultures and incubated in a BOD incubator for $48 \mathrm{~h}$ at $28 \pm 1^{\circ} \mathrm{C}$. Bacterial isolates that grew in a medium supplemented with $\mathrm{NaCl}$ at a concentration higher than $5 \%$ were considered as salt stress-resistant isolates and examined in vitro for temperature stress $\left(25-40^{\circ} \mathrm{C}\right), \mathrm{pH}$ stress $(5-8)$, and PGP attributes.

The results for the growth of bacterial strains were scored as binary numbers: 1 representing growth and 0 indicating no growth. The data were subjected to cluster analysis using PAST 3.22 software. 


\section{Effect on plant growth}

Effect of the halophilic isolate BoGl21 on plant growth was analyzed with wheat ( $T$. aestivum) and corn (Zea mays) seeds. Crop seeds were obtained from IARI, Pusa, Delhi, India. The seeds were washed with sterilized distilled water three times and surface sterilized with $3 \%$ sodium hypochlorite $(\mathrm{NaOCl})$ for $5 \mathrm{~min}$. The seeds were washed five times with sterilized distilled water for removing any traces of $\mathrm{NaOCl}$. Subsequently, the seeds were dipped and left for $20 \mathrm{~min}$ in bacterial culture in a conical flask (48-h-old bacterial growth with $9 \log _{10} \mathrm{CFU} / \mathrm{g}$ and air dried in a laminar air flow cabinet for $60 \mathrm{~min}$. Air-dried bacterial-coated seeds were planted in earthen pots (five seeds per pot) at Bhojia Institute of Life Sciences greenhouse in August. For every treatment, three replicates were prepared. The trials for both crops were designed in the following manner:

- control (PGPC1): unsterilized garden soil and wheat seeds dipped in $10 \mathrm{ml}$ of uninoculated nutrient broth medium;

- PGPT1: unsterilized garden soil and wheat seeds coated with bacterial strain BoG121 and

- PGPT2: unsterilized garden soil and corn seeds coated with bacterial strain BoGl21;

- control (PGPC2): unsterilized garden soil and corn seeds dipped in $10 \mathrm{ml}$ of uninoculated nutrient broth medium;

- PGPT3: unsterilized garden soil and wheat seeds coated with bacterial strain BoGl17; and

- PGPT4: unsterilized garden soil and corn seeds coated with bacterial strain BoGl17.

A randomized block design was used for the layout of the pots under natural environment and growth parameter data, i.e., shoot length, root length, and total dry weight recorded after 60 days.

\section{Characterization and identification of the bacterial isolates}

Microscopic, biochemical, and molecular methods were used for the identification of two most promising bacterial isolates. Biochemical identification of BoG121 was performed as described in Bergey's Manual of Determinative Bacteriology (Holt et al., 1994). For phenotypic characterization, Gram's staining, motility testing, and endospore staining were performed (Karnwal and Kaushik, 2011).

Phylogenetic analysis and 16S ribosomal RNA sequencing were performed for both bacterial isolates. $16 \mathrm{~s}$
rRNA was isolated using the Qiagen DNeasy Plant Mini Kit (Qiagen). Gene amplification, thermocycling conditions, and sequence analysis were described earlier in detail (Gulati et al., 2008). The MUSCLE algorithm was used for multiple sequence alignment (MSA) with sequences collected from BLAST and MEGA X software. Kimura 2-parameter substitution model and neighborjoining statistical method were used for computing the evolutionary distance of the salt stress-tolerant bacterial strains for phylogenetic analysis.

\section{Trial design and statistical analysis}

All trials were performed by applying a randomized block design during experiments. Unless stated otherwise, all values are expressed as standard means of three replicates. Data on plant growth promotion were analyzed by analysis of variance (ANOVA). The mean of the treatments was compared by Fisher's significant difference (LSD) test at $\mathrm{p}$ values of 0.05 .

\section{Results and discussion}

\section{Isolation of bacterial endophytes}

In natural environment, plants have to combat various biotic and abiotic stresses (Balseiro-Romero et al., 2017). Abiotic stressors are classified as inanimate components associated with the environment whose effect is experienced by the living organisms of nature (Jasim et al., 2015). Nutrients, salt concentration, water availability, temperature change, and $\mathrm{pH}$ are the main abiotic factors that directly influence plant growth in agricultural fields (Kumar and Verma, 2018). Many researchers (Mahmood et al., 2016; Etesami and Maheshwari, 2018; Noori et al., 2018) observed and revealed the use of beneficial microorganisms in agricultural fields to combat the increase in salt tolerance in plants, which can be utilized as a substitute method for farming in susceptible salt fields. PGPR are bacteria that reside in soil near the plant roots and effectively participate in plant growth and development, and abiotic stress tolerance. These microorganisms enhance soil-water-plant relationships, manipulate phytohormonal signaling, and trigger several other mechanisms that work in an integrated manner to enhance salt and drought stress tolerance in plants (Kumar et al., 2015).

In the present study, a total of 28 bacterial endophytes from the leaf samples of $B$. glabra (designated as 
Table 1. Micro- and macroscopic characteristics of bacterial isolates

\begin{tabular}{l|c|c|c|c|c}
\hline Bacterial isolate & Shape & Color & Margin & Elevation & Gram stain \\
\hline BoG15 & rod & pale yellow & circular & convex & - \\
\hline BoG18 & cocci & yellow & irregular & raised & - \\
\hline BoGl17 & rod & cream & circular & convex & - \\
\hline BoGl21 & rod & whitish & irregular & raised & + \\
\hline BoG126 & cocci & whitish & circular & raised & - \\
\hline
\end{tabular}

Table 2. Screening of bacterial isolates for phosphate solubilization ability

\begin{tabular}{|c|c|c|c|c|}
\hline \multirow{2}{*}{$\begin{array}{l}\text { Bacterial } \\
\text { isolate }\end{array}$} & \multicolumn{2}{|c|}{ Phosphate solubilization efficiency } & \multirow{2}{*}{$\begin{array}{c}\text { Phosphate } \\
\text { solubilization index }\end{array}$} & \multirow{2}{*}{$\begin{array}{c}\text { Phosphate } \\
\text { solubilization } \\
{[\mu \mathrm{g} / \mathrm{ml}]}\end{array}$} \\
\hline & $\begin{array}{c}\text { colony diameter } \\
{[\mathrm{mm}]}\end{array}$ & $\begin{array}{l}\text { Halo zone diameter } \\
{[\mathrm{mm}]}\end{array}$ & & \\
\hline BoG15 & $10 \pm 0.02$ & 0 & $1.00 \pm 0.02$ & 0 \\
\hline BoG18 & $1 \pm 0.07$ & 0 & $1.00 \pm 0.03$ & 0 \\
\hline BoGl17 & $2 \pm 0.01$ & $12 \pm 0.02$ & $7.00 \pm 0.01$ & $176.21 \pm 0.02$ \\
\hline BoGl21 & $6 \pm 0.12$ & $38 \pm 0.08$ & $7.33 \pm 0.01$ & $214.59 \pm 0.21$ \\
\hline BoGl26 & $1.5 \pm 0.03$ & $8 \pm 0.02$ & $6.33 \pm 0.05$ & $103.83 \pm 0.04$ \\
\hline
\end{tabular}

Values are the mean of three replicates $\pm \mathrm{SE}_{\text {mean }}$

BoGl1 to BoG128) were screened. Of these 28 isolates, 5 isolates (BoGl5, BoGl8, BoGl17, BoG121, and BoG126) were reported to exhibit salt tolerance and were subcultured on $\mathrm{NaCl}$ (4\%)-supplemented NAM for further studies. Colony characteristics of the 5 isolates are shown in Table 1. All the 5 isolates formed irregular to circular colonies. The elevation of colonies of BoGl17, BoGl21, and BoG126 was raised, while that of BoG15 and BoG18 was convex. The colony margin, colony color, and Gram staining results varied significantly between all bacterial isolates as shown in Table 1. The bacterial isolates BoGl5, BoG18, BoGl17, and BoGl26 were gramnegative isolates, while BoGl21 was a gram-positive isolate. Colony appearance results revealed that the isolates BoG15, BoG117, and BoGl21 were rod in shape, while BoG18 and BoG126 were cocci. It has been observed that the variety and type of endophytic microorganisms vary depending on natural host plants. Several researchers (Khalifa et al., 2016; Nascimento et al., 2016) have reported lesser amounts of endophytic bacteria in plants (4 $\log _{10}$ to $8 \log _{10} \mathrm{CFU} / \mathrm{g}$ of plant tissue) than rhizospheric bacteria (6 $\log _{10}$ to $9 \log _{10} \mathrm{CFU} / \mathrm{g}$ of soil) in a host crop. In recent years, numerous biochemical pathways used by endophytes for enhancing plant develop- ment under various abiotic stresses were reported in scientific studies (Jasim et al., 2015). These include phytohormone production, ACC deaminase activity, $\mathrm{HCN}$ production, organic acid production for solubilization of minerals, and antagonistic activity (Edi-Premono et al., 1996; Carlos et al., 2016; Kumar and Verma, 2018). The 5 bacterial isolates studied in this research study were further assessed for their PGP traits, i.e., IAA production, phosphate liquefaction, siderophore production, ACC deaminase activity, and HCN production.

Phosphorus is a macronutrient required by all living organisms. Plants require this particular macronutrient in an extremely low amount, although a critically low availability could lead to deficiencies and adverse effect on plant growth (Karnwal, 2017). For optimum growth, plants require phosphorus in the range of 25 to $30 \mu \mathrm{mol} / 1$, but the actual amount of phosphorus available in most soil type ranges only from 1 to $1.7 \mu \mathrm{mol} / 1$ (Melo et al., 2016). Phosphorus is present in soil in organic compounds and minerals. Nevertheless, the amount of readily available phosphorus for plants is very low compared with the total amount of phosphorus in the soil. Previous studies (Perrig et al., 2007; Masciarelli et al., 2014) revealed the use of residing soil bacteria for lique- 
Table 3. Screening profile of bacterial isolates for various PGP traits

\begin{tabular}{c|c|c|c|c|c}
\hline $\begin{array}{c}\text { Bacterial } \\
\text { isolate }\end{array}$ & $\begin{array}{c}\text { IAA-like auxin production } \\
{[\mu \mathrm{g} / \mathrm{ml}]}\end{array}$ & $\begin{array}{c}\mathrm{HCN} \\
\text { production }\end{array}$ & $\begin{array}{c}\text { Ammonia } \\
\text { production }\end{array}$ & $\begin{array}{c}\text { Siderophore } \\
\text { production zone } \\
{[\mathrm{mm}]}\end{array}$ & $\begin{array}{c}\text { ACC deaminase } \\
\text { activity }\end{array}$ \\
\hline BoGl5 & $0.26 \pm 0.01$ & ++ & - & $1.8 \pm 0.47$ & - \\
\hline BoGl8 & $2.7 \pm 1.51$ & - & + & $8.2 \pm 1.62$ & - \\
\hline BoGl17 & $12.7 \pm 2.47$ & ++ & - & $12.6 \pm 1.54$ & + \\
\hline BoGl21 & $28.1 \pm 1.38$ & +++ & +++ & $18.8 \pm 1.82$ & +++ \\
\hline BoGl26 & $6.62 \pm 2.10$ & + & - & $8.1 \pm 0.61$ & + \\
\hline
\end{tabular}

Values are the mean of three replicates $\pm \mathrm{SE}_{\text {mean }} ;+++-$ luxuriant growth/strong activity, ++- good growth/moderate activity, + - poor growth/weak activity, - - no growth/no activity

faction of mineral phosphates into a plant utilizable form. The results of the phosphate solubilizing assay showed that only three isolates had bright areas surrounding the bacterial growth with zone diameter ranging from 8 to $38 \mathrm{~mm}$ as positive phosphate solubilizer, and the phosphate solubilization index ranged from 6.33 to 7.33 for the phosphate solubilizing isolates (Table 2). The phosphate solubilizing efficiency test in $0.5 \%$ tri-calcium phosphate-supplemented Pikovskaya's broth suggested that 3 bacterial isolates successfully liquefied mineral phosphate in the inoculated broth (Table 2). Phosphate solubilizing bacteria (PSB) BoGl17, BoGl21 and BoGl26 were estimated with $176.21,214.59$ and $103.83 \mu \mathrm{g} / \mathrm{ml}$ soluble phosphate, respectively, after $48 \mathrm{~h}$ of incubation period. Phosphate solubilizing efficiencies of other strains are reported in Table 2. Inorganic phosphate solubilization by microorganisms is of economic importance in crop nourishment, and previous studies (Haiyambo et al., 2015; Carlos et al., 2016) have already reported the application of numerous soil bacteria genera such as Achromobacter, Pseudomonas, Flavobacterium, Enterobacter, Serratia, Bacillus, Mycobacterium, Erwinia, Agrobacterium, and Escherichia as phosphate solubilizers.

Production of IAA is one of the most critical traits of a wide variety of soil microorganisms used as plant growth promoters. IAA is a plant developmental hormone associated with rhizome propagation, plant cell proliferation, and cell duplication, and therefore, IAA biosynthetic activity of microorganisms is essential for plant development (Karnwal and Dohroo, 2018). Among all the reported auxins, IAA is the essential growth enhancer for plant root system development (Glick, 1995). Karnwal (2009) reported the significance of rhizo-competent stress-resistant microorganisms with diverse functions primarily responsible for the elimination of salt stress in crops. In the present study, all 5 isolates were analyzed for IAA production in terms of the availability of L-tryptophan and showed positive attribute for IAA production ranging from 0.26 to $28.1 \mu \mathrm{g} / \mathrm{ml}$ as shown in Table 3. The isolates BoGl17 and BoGl21 produced the maximum level of IAA in broth: 12.7 and $28.1 \mu \mathrm{g} / \mathrm{ml}$, respectively. The strains BoGl5, BoGl8, and BoGl26 produced small amounts of IAA $(0.26,2.7$, and $6.63 \mu \mathrm{g} / \mathrm{ml}$, respectively). The biosynthesis of iron-scavenging siderophores is a valuable process of PGPRs (Chauhan et al., 2016) consisting of a dual effect of promoting plant development by increasing beneficial nutrient supply for plants and by lowering iron supply to soil-borne phytopathogens. PGPRs in soil can also produce ACC deaminase and promote plant growth as well as protect the plant against abiotic (drought, salt, flooding, and inorganic and organic contaminants) (Benidire et al., 2016) and biotic (bacterial and fungal pathogens) stresses. In our study, 4 isolates showed positive results for $\mathrm{HCN}$ production, 2 for ammonia production, 5 for siderophore production, and 3 for ACC deaminase activity as shown in Table 3. These secondary metabolites have an instant effect on shoot and root development and seed growth of various agricultural crops.

Based on all PGP trait results, the best stress-tolerant PGP endophytic isolates (BoGl17 and BoGl21) were selected for further studies.

\section{Screening for stress tolerance}

During the process of evolution, microorganisms have established a variety of mechanisms to cope up while living in a stress environment. Several bacterial genera such as Azotobacter, Bacillus, Pseudomonas, and 
Rhizobium are competent to withstand abiotic stresses by synthesizing a significant amount of exopolysaccharides (EPS) (Torres et al., 2019). In recent years, it has been revealed that bacteria belonging to different genera such as Rhizobium, Bacillus, Pseudomonas, Burkholderia, Achromobacter, Methylobacterium, and Variovorax can provide tolerance to host plants against different abiotic stresses (Passari et al., 2016). These microorganisms can void the environmental stress in farming and are useful for decreasing soil salinity. In the present study, the bacterial isolates BoGl17 and BoGl21 were tested for stress tolerance against varying levels of salinity, $\mathrm{pH}$, and temperature. The salinity study revealed that the selected isolates could tolerate higher $\mathrm{NaCl}$ concentration in agar medium. The selected isolates showed good growth on $5 \%(0.86 \mathrm{M}), 7 \%(1.2 \mathrm{M})$, and $8.5 \%$ $(1.46 \mathrm{M})$ salt concentration. BoGl21 could tolerate $10 \%$ $\mathrm{NaCl}$ concentration, whereas no growth was observed at $12 \% \mathrm{NaCl}$ concentration. Similarly, the growth of BoGl17 was observed on agar supplemented with $10 \% \mathrm{NaCl}$ concentration, and no growth was observed above this concentration. Variable growth was observed on media adjusted to different $\mathrm{pH}$ values. The optimum $\mathrm{pH}$ value for BoGl21 growth was 6 , while the strain also grew on medium with $\mathrm{pH} 5$ and 7; however, no growth was observed at $\mathrm{pH} 8$. The BoGl17 strain could grow on media with $\mathrm{pH} 5,6,7$ and 8 . The temperature stress study revealed that the bacterial isolates exhibited growth at different temperatures ranging from 25 to $40^{\circ} \mathrm{C}$.

Dendrogram created using UPGMA cluster analysis (similarity index: Euclidean) for stress tolerance at different levels of salinity, temperature, and $\mathrm{pH}$ for bacterial isolates showed three clusters: cluster 1 contained 2 isolates (BoGl17 and BoGl21), cluster 2 contained 2 isolates (BoGl26 and BoGl5), and cluster 3 had one isolate (BoGl8), as shown in Figure 1.

\section{Effect of BoG121 and BoG117 on plant growth promotion}

The potential use of PGPRs in the alleviation of salt stress in plants has been reported by many researchers in various plants, including licorice, and chili pepper (Zhang et al., 2014; Zhou et al., 2017). In a previous study, the inoculation effect of PGPRs at early developmental stages of rice was reported, and better plant development and biomass production through direct effects on root and shoot development were observed (Karnwal, 2009). In the present study, 60 days after

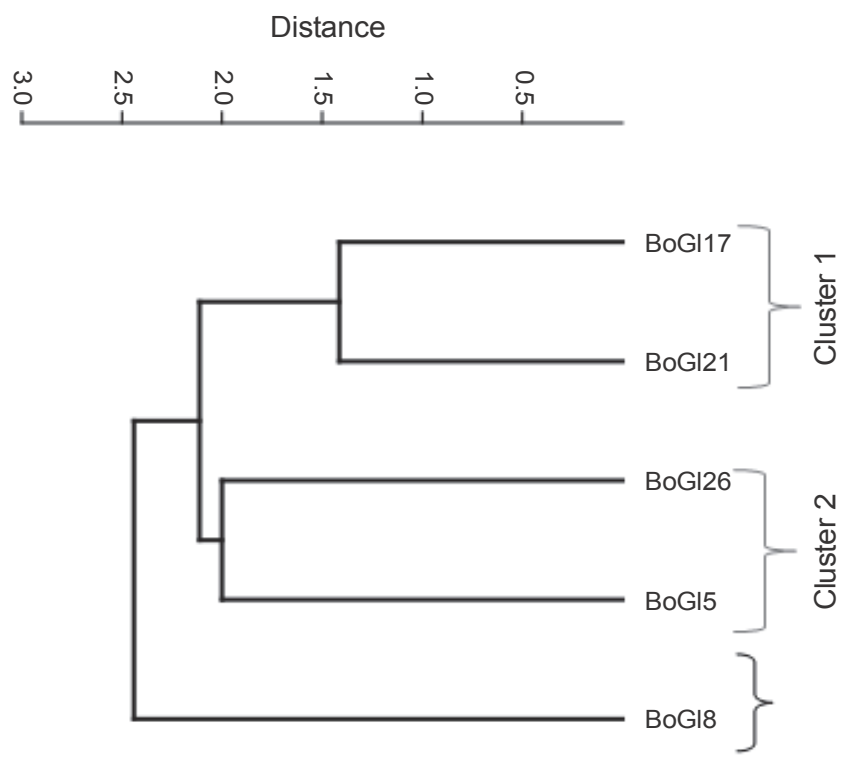

Fig. 1. Dendrogram based on UPGMA cluster analysis (similarity index: Euclidean) by using PAST software 3.22 for salt-tolerant isolates of Bougainvillea glabra using growth pattern data for different stress levels (salinity, temperature, and $\mathrm{pH}$ stress)

sowing, all wheat and corn plants were harvested for analysis, and the average of three replicates for each isolate was used for statistical analysis. Results of the pot study showed that the selected bacterial isolates significantly $(P \leq 0.05)$ increased the growth parameters of wheat and corn as compared to those of the control plant (Table 4). In the greenhouse pot experiment, the application of BoGl17 and BoGl21 on wheat significantly increased shoot length, root length, shoot dry weight, and root dry weight by 32 and $61.5 \%, 35.78$ and $56.55 \%$, 40 and $80 \%$, and 60 and $126.2 \%$, respectively, as compared to those of the control plant. Similar results were obtained for corn with both isolates, where BoGl17 and BoGl21 increased shoot length, root length, shoot dry weight, and root dry weight by 56 and $21.8 \%, 7$ and $44 \%$, 120 and $75 \%$, and 135.1 and $32.4 \%$, respectively, as compared to those of the control plant.

Salt stress negatively affects plant development and decreases product formation (Potshangbam et al., 2017). In an earlier study, Egamberdieva and Kucharova (2009) reported the positive effect of salt-tolerant $P$ seudomonas extremorientalis strain on root colonization and development of tomato. Dixit et al. (2018) also demonstrated that salt-tolerant bacteria Paenibacillus lentimorbus showed best efficiency during the development of tomato in nonsaline and saline soils. Our results also support the 
Table 4. Effect of stress-tolerant bacterial endophytes on growth promotion of wheat and corn

\begin{tabular}{l|c|c|c|c|c|c|c|c|}
\hline \multirow{2}{*}{ Bacterial isolates } & \multicolumn{4}{|c|}{ Wheat } & \multicolumn{4}{c}{ Corn } \\
\cline { 2 - 9 } & $\begin{array}{c}\text { Shoot } \\
\text { length } \\
{[\mathrm{cm}]}\end{array}$ & $\begin{array}{c}\text { Root } \\
\text { length } \\
{[\mathrm{cm}]}\end{array}$ & $\begin{array}{c}\text { Shoot } \\
\text { dry weight } \\
{[\mathrm{g}]}\end{array}$ & $\begin{array}{c}\text { Root } \\
\text { dry weight } \\
{[\mathrm{g}]}\end{array}$ & $\begin{array}{c}\text { Shoot } \\
\text { length } \\
{[\mathrm{cm}]}\end{array}$ & $\begin{array}{c}\text { Root } \\
\text { length } \\
{[\mathrm{cm}]}\end{array}$ & $\begin{array}{c}\text { Shoot } \\
\text { dry weight } \\
{[\mathrm{g}]}\end{array}$ & $\begin{array}{c}\text { Root } \\
\text { dry weight } \\
{[\mathrm{g}]}\end{array}$ \\
\hline BoG117 & $21.29^{\mathrm{b}}$ & $13.47^{\mathrm{b}}$ & $0.07^{\mathrm{b}}$ & $0.071^{\mathrm{ab}}$ & $31.78^{\mathrm{c}}$ & $11.37^{\mathrm{a}}$ & $0.44^{\mathrm{c}}$ & $0.341^{\mathrm{c}}$ \\
\hline BoG121 & $26.04^{\mathrm{c}}$ & $15.53^{\mathrm{b}}$ & $0.09^{\mathrm{c}}$ & $0.095^{\mathrm{b}}$ & $24.80^{\mathrm{b}}$ & $15.33^{\mathrm{b}}$ & $0.35^{\mathrm{b}}$ & $0.192^{\mathrm{b}}$ \\
\hline Control & $16.12^{\mathrm{a}}$ & $9.92^{\mathrm{a}}$ & $0.05^{\mathrm{a}}$ & $0.042^{\mathrm{a}}$ & $20.36^{\mathrm{a}}$ & $10.62^{\mathrm{a}}$ & $0.20^{\mathrm{a}}$ & $0.145^{\mathrm{a}}$ \\
\hline LSD value at $5 \%$ & 1.42 & 3.17 & 0.012 & 0.031 & 3.76 & 2.62 & 0.012 & 0.037 \\
\hline
\end{tabular}

Values are the mean of three replicates with five plants each $\pm \mathrm{SE}_{\text {mean }}$; values with different letters in each column differ significantly from one another at $P \leq 0.05 ;$ LSD - least square difference
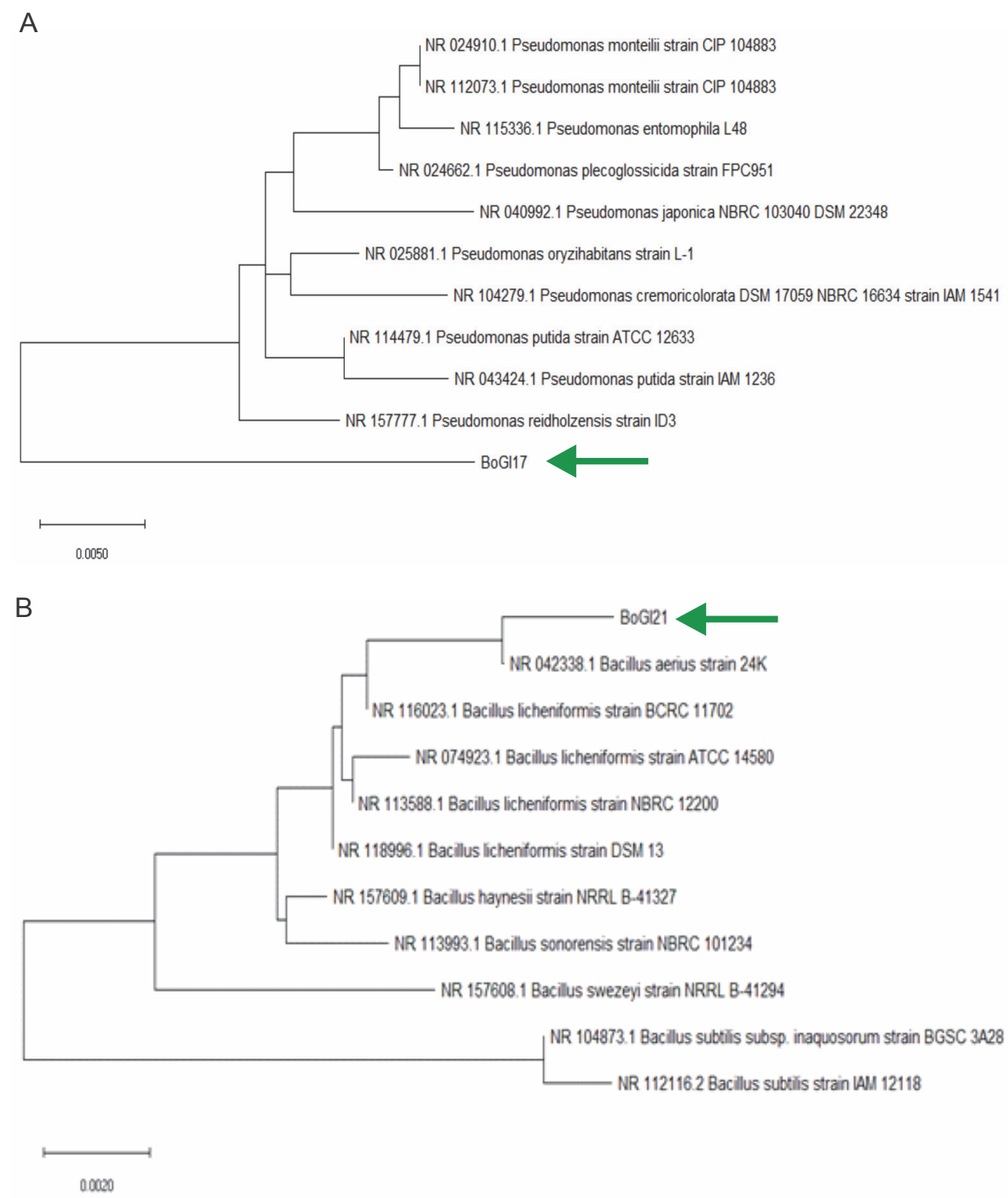

Fig. 2. Phylogenetic tree of bacterial isolates based on $16 \mathrm{~S}$ rRNA sequence similarity by using MEGA X software:

A) BLAST similarity search results and phylogenetic tree for isolate BoGl21 and B) for BoGl17 
results of other studies as the shoot length $(26.04 \mathrm{~cm})$ and root length $(15.53 \mathrm{~cm})$ were the longest in BoGl21inoculated wheat, while plant growth promotion by BoG117 (shoot length: $21.29 \mathrm{~cm}$ and root length: $13.47 \mathrm{~cm}$ ) was significantly better than that observed for uninoculated wheat. Almaghrabi et al. (2013) reported that the application of salt stress-tolerant Pseudomonas putida and Pseudomonas fluorescens improved tomato growth parameters. The highest value of shoot dry weight/g was found in the plant treated with $P$. putida (34.33 g), followed by P. fluorescens ( $30 \mathrm{~g}$ ) and nematode alone (untreated, $20 \mathrm{~g}$ )/plant. The highest value of plant height was observed for plant treated with $P$. fluorescens, followed by plant treated with $P$. putida (50.66 and $48 \mathrm{~cm}$, respectively) (Almaghrabi et al. 2013).

Earlier reports (Karnwal and Kaushik, 2011; Almaghrabi et al., 2013) demonstrated that bacterial inoculants improved root growth, which facilitated the development of rice and tomato, and increased the overall access of plant roots to soil minerals, i.e., nitrogen $(\mathrm{N})$, phosphorus $(\mathrm{P})$, and potassium $(\mathrm{K})$. The present study showed that in the case of corn seeds, root length was higher when seeds were inoculated with BoGl21 $(15.33 \mathrm{~cm})$ than with BoGl17 $(11.37 \mathrm{~cm})$ and uninoculated $(10.62 \mathrm{~cm})$ treatment. Root dry weight was higher in BoGl21 (0.095 g and $0.192 \mathrm{~g})$ and BoGl17 $(0.071 \mathrm{~g}$ and $0.341 \mathrm{~g})$ treatments $(P \leq 0.05)$ than in uninoculated treatment for both wheat and corn, respectively. Shoot dry weight was increased in BoGl17 treatment $(0.44 \mathrm{~g})$ for corn and BoGl21 treatment $(0.09 \mathrm{~g})$ for wheat $(P \leq 0.05)$ (Table 4$)$.

\section{Characterization and identification of the bacterial isolates}

Earlier reports showed that Proteobacteria, Firmicutes, Actinobacteria, and Bacteroidetes are the most abundant bacterial phyla of plant endophytic bacteria that participate in plant growth promotion (Passari et al., 2016). The most commonly found genera of bacterial endophytes are Microbacterium, Pseudomonas, Burkholderia, Stenotrophomonas, Bacillus, Pantoea, and Micrococcus (Taghavi et al., 2015; Heydarian et al., 2016). Microscopic, biochemical, and molecular methods were used for the characterization and identification of BoGl21 bacterial isolates. Microscopy results revealed that the bacterial isolates BoGl17 and BoGl21 were rod-shaped bacilli, gram-negative (BoGl17), or gram-positive (BoGl21).
The 16S rRNA gene sequencing method was used for the molecular characterization of bacterial isolates. The 16s rRNA gene sequence of BoGl17 showed 95.59\% identity with that of Pseudomonas reidholzensis strain ID3, while the 16S rRNA gene sequence of BoGl21 showed $90.96 \%$ identity with those of Bacillus aerius strain 24K and Bacillus licheniformis strain DSM 13 (90.45\%) as shown in Figure 2. The phylogenetic tree for BoGl21 was constructed using MEGA X software and shown in Figure 2.

\section{Conclusions}

The results of the present study confirmed that the growth of both crops (wheat and corn) improved in the presence of inoculated salinity stress-tolerant bacterial endophytes. Inoculation of salt-tolerant isolates showed sufficient incline in shoot and root length and shoot and root dry weight. These improvements in plant growth traits were related to phytohormone production (auxinsIAA), phosphate liquefaction, siderophore production, ACC deaminase activity, and $\mathrm{HCN}$ and ammonia production by the inoculated bacterial isolates, which suggests that the use of salinity stress-tolerant bacteria is helpful and beneficial for enhancing the growth of wheat and corn.

\section{Acknowledgment}

I am very thankful to Bhojia Institute of Life Sciences, Budh, Baddi, Himachal Pradesh, India, for technical support to complete this study and for their unlimited help in all steps of the study.

\section{References}

Abedinzadeh M., Etesami H., Alikhani H.A. (2019) Characterization of rhizosphere and endophytic bacteria from roots of maize (Zea mays L.) plant irrigated with wastewater with biotechnological potential in agriculture. Biotechnol. Rep. (Amst) 21: e00305.

Akter S., Kadir J., Juraimi A.S., Saud H.M. (2016) In vitro evaluation of pseudomonas bacterial isolates from rice phylloplane for biocontrol of rhizoctonia solani and plant growth promoting traits. J. Environ. Biol. 37: 597-602.

Almaghrabi O.A., Massoud S.I., Abdelmoneim T.S. (2013) Influence of inoculation with plant growth promoting rhizobacteria (PGPR) on tomato plant growth and nematode reproduction under greenhouse conditions. Saudi J. Biol. Sci. 20(1): 57-61.

Armada E., Probanza A., Roldan A., Azcon R. (2016) Native plant growth promoting bacteria bacillus thuringiensis and mixed or individual mycorrhizal species improved drought 
tolerance and oxidative metabolism in lavandula dentata plants. J. Plant. Physiol. 192: 1-12.

Balseiro-Romero M., Gkorezis P., Kidd P.S., Van Hamme J., Weyens N., Monterroso C., Vangronsveld J. (2017) Use of plant growth promoting bacterial strains to improve cytisus striatus and lupinus luteus development for potential application in phytoremediation. Sci. Total. Environ. DOI 10.1016/j.scitotenv.2016.12.180.

Benidire L., Pereira S.I., Castro P.M., Boularbah A. (2016) Assessment of plant growth promoting bacterial populations in the rhizosphere of metallophytes from the kettara mine marrakech. Environ. Sci. Pollut. Res. Int. 23(21): 21751-21765.

Carlos M.H., Stefani P.V., Janette A.M., Melani M.S., Gabriela P.O. (2016) Assessing the effects of heavy metals in ACC deaminase and IAA production on plant growth-promoting bacteria. Microbiol. Res. 188-189: 53-61.

Chauhan A.K., Maheshwari D.K., Kim K., Bajpai V.K. (2016) Termitarium-inhabiting bacillus endophyticus TSH42 and bacillus cereus TSH77 colonizing Curcuma longa L.: isolation characterization and evaluation of their biocontrol and plant-growth-promoting activities. Can. J. Microbiol. 62(10): 880-892.

Dixit R., Agrawal L., Singh S.P., Prateeksha Singh P.C., Prasad V., Chauhan P.S. (2018) Paenibacillus lentimorbus induces autophagy for protecting tomato from sclerotium rolfsii infection. Microbiol. Res. 215: 164-174.

Dworkin M., Foster J. (1958) Experiments with some microorganisms which utilize ethane and hydrogen. J. Bacteriol. 75: 592-601.

Edi-Premono M., Moawad A.M., Vleck P.L.G. (1996) Effect of phosphate solubilizing pseudomonas putida on the growth of maize and its survival in the rhizosphere. Indones. J. Agric. Sci. 11: 13-23.

Egamberdieva D., Kucharova Z. (2009) Selection for root colonising bacteria stimulating wheat growth in saline soils. Biol. Fert. Soils. 45: 561-573.

Etesami H., Maheshwari D.K. (2018) Use of plant growth promoting rhizobacteria (PGPRs) with multiple plant growth promoting traits in stress agriculture: action mechanisms and future prospects. Ecotoxicol. Environ. Saf. 156: 225-246.

FAO (2009) How to feed the world in 2050. Insights from an expert meeting at FAO. 2050: 1-35.

Glick B.R (1995) The enhancement of plant growth by freeliving bacteria. Can. J. Microbiol. 41: 109-117.

Glick B.R., Bashan Y. (1997) Genetic manipulation of plant growth-promoting bacteria to enhance biocontrol of phytopathogens. Biotechnol. Adv. 15: 353-378.

Gulati A., Rahi P., Vyas P. (2008) Characterization of phosphate solubilizing fluorescent pseudomonads from rhizosphere of seabuckthorn growing in cold deserts of himalayas. Curr. Microbiol. 56: 73-79.

Gupta R., Singal R., Shanker A., Kuhad R.C., Saxena R.K. (1994) A modifi ed plate assay for screening phosphate solubilizing microorganisms. J. Gen. Appl. Microbiol. 40: 255-260.
Haiyambo D.H., Chimwamurombe P.M., Reinhold-Hurek B. (2015) Isolation and screening of rhizosphere bacteria from grasses in east kavango region of namibia for plant growth promoting characteristics. Curr. Microbiol. 71(5): 566-571.

Hemambika B., Kannan V.R. (2012) Intrinsic characteristics of $C R(6)(+)$-resistant bacteria isolated from an electroplating industry polluted soils for plant growth-promoting activities. Appl. Biochem. Biotechnol. 167(6): 1653-1667.

Heydarian Z., Yu M., Gruber M., Glick B.R., Zhou R., Hegedus D.D. (2016) Inoculation of soil with plant growth promoting bacteria producing 1-aminocyclopropane-1-carboxylate deaminase or expression of the corresponding acds gene in transgenic plants increases salinity tolerance in Camelina sativa. Front. Microbiol. 7: 1966.

Holt J.G., Krieg N.R., Sneath P.H.A., Staley J.T., Williams S.T. (1994) Bergey's manual of determinative bacteriology. Williams \& Wilkins. Baltimore 1994.

Jasim B., Anish M.C., Shimil V., Jyothis M., Radhakrishnan E.K. (2015) Studies on plant growth promoting properties of fruit-associated bacteria from elettaria cardamomum and molecular analysis of acc deaminase gene. Appl. Biochem. Biotechnol. 177(1): 175-189.

Karnwal A. (2009) Production of indole acetic acid by fluorescent pseudomonas in the presence of l-tryptophan and rice root exudates. J. Plant. Path. 19(1): 61-63.

Karnwal A. (2017) Isolation and identification of plant growth promoting rhizobacteria from maize (Zea mays L.) rhizosphere and their plant growth promoting effect on rice (Oryza sativa L.). J. Plant Prot. Res. 57(2): 144-151.

Karnwal A., Dohroo A. (2018) Effect of maize root exudates on indole-3-acetic acid production by rice endophytic bacteria under influence of 1-tryptophan. F1000Res. 7: 112.

Karnwal A., Kaushik P. (2011) Cytokinin production by fluorescent pseudomonas in the presence of rice root exudates. Arch. Phytopathology. Plant. Protect. 44(17): 1728-1735.

Khalifa A.Y., Alsyeeh A.M., Almalki M.A., Saleh F.A. (2016) Characterization of the plant growth promoting bacterium enterobacter cloacae MSR1, isolated from roots of nonnodulating Medicago sativa. Saudi. J. Biol. Sci. 23(1): 79-86.

Kumar A., Verma J.P. (2018) Does plant-microbe interaction confer stress tolerance in plants: a review? Microbiol. Res. 207: 41-52.

Kumar P., Dubey R.C., Maheshwari D.K. (2012) Bacillus strains isolated from rhizosphere showed plant growth promoting and antagonistic activity against phytopathogens. Microbiol. Res. 167: 493-499.

Kumar V., Singh S., Singh J., Upadhyay N. (2015) Potential of plant growth promoting traits by bacteria isolated from heavy metal contaminated soils. Bull. Environ. Contam. Toxicol. 94(6): 807-814.

Macauley H. (2015) Cereal crops: Rice maize millet sorghum wheat. Feeding Africa: an action plan for African Agricultural transformation. DOI 10.1002/yd.383. 
Mahmood S., Daur I., Al-Solaimani S.G., Ahmad S., Madkour M.H., Yasir M., Hirt H., Ali S., Ali Z. (2016) Plant growth promoting rhizobacteria and silicon synergistically enhance salinity tolerance of mung bean. Front. Plant. Sci. 7: 876.

Masciarelli O., Llanes A., Luna V. (2014) A new PGPR co-inoculated with bradyrhizobium japonicum enhances soybean nodulation. Microbiol. Res. 169(7-8): 609-615.

Myresiotis C.K., Vryzas Z., Papadopoulou-Mourkidou E. (2015) Effect of specific plant-growth-promoting rhizobacteria (PGPR) on growth and uptake of neonicotinoid insecticide thiamethoxam in corn (Zea mays L.) seedlings. Pest. Manag. Sci. 71: 1258-1266.

Nascimento F.X., Espada M., Barbosa P., Rossi M.J., Vicente C.S., Mota M. (2016) Non-specific transient mutualism between the plant parasitic nematode Bursaphelenchus xylophilus and the opportunistic bacterium Serratia quinivorans $B X F 1$, a plant-growth promoting pine endophyte with antagonistic effects. Environ. Microbiol. 18(12): 5265-5276.

Nehra V., Saharan B.S., Choudhary M. (2016) Evaluation of Brevibacillus brevis as a potential plant growth promoting rhizobacteria for cotton (Gossypium hirsutum) crop. Springerplus. 5: 948.

Noori F., Etesami H., Najafi Zarini H., Khoshkholgh-Sima N.A., Hosseini Salekdeh G., Alishahi F. (2018) Mining alfalfa (Medicago sativa L.) nodules for salinity tolerant non-rhizobial bacteria to improve growth of alfalfa under salinity stress. Ecotoxicol. Environ. Saf. 162: 129-138.

Passari A.K., Mishra V.K., Leo V.V., Gupta V.K., Singh B.P. (2016) Phytohormone production endowed with antagonistic potential and plant growth promoting abilities of culturable endophytic bacteria isolated from clerodendrum colebrookianum walp. Microbiol. Res. 193: 57-73.

Perrig D., Boiero M.L., Masciarelli O.A., Penna C., Ruiz O.A., Cassan F.D., Luna M.V. (2007) Plant-growth-promoting compounds produced by two agronomically important strains of azospirillum brasilense and implications for inoculant formulation. Appl. Microbiol. Biotechnol. 75(5): 1143-1150.

Potshangbam M., Devi S.I., Sahoo D., Strobel G.A. (2017) Functional characterization of endophytic fungal community associated with Oryza sativa L. and Zea mays L. Front. Microbiol. 8: 325.

Sarkar A., Pramanik K., Mitra S., Soren T., Maiti T.K. (2018) Enhancement of growth and salt tolerance of rice seedlings by ACC deaminase-producing Burkholderia sp. Mtcc 12259. J. Plant. Physiol. 231: 434-442.
Shrivastava P., Kumar R. (2015) Soil salinity: a serious environmental issue and plant growth promoting bacteria as one of the tools for its alleviation. Saudi. J. Biol. Sci. 22(2): 123-131.

Taghavi S., Wu X., Ouyang L., Zhang Y.B., Stadler A., McCorkle S., Zhu W., Maslov S., van der Lelie D. (2015) Transcriptional responses to sucrose mimic the plant-associated life style of the plant growth promoting endophyte enterobacter sp. 638. PLoS. One. 10(1): e0115455.

Tak H.I., Ahmad F., Babalola O.O. (2013) Advances in the application of plant growth-promoting rhizobacteria in phytoremediation of heavy metals. Rev. Environ. Contam. Toxicol. 223: 33-52.

Torres M., Dessaux Y., Llamas I. (2019) Saline environments as a source of potential quorum sensing disruptors to control bacterial infections: a review. Mar. Drugs. 17(3): 191.

Ullah I., Al-Johny B.O., Al-Ghamdi K.M.S., Al-Zahrani H.A.A., Anwar Y., Firoz A., Al-Kenani N., Almatry M.A.A. (2019) Endophytic bacteria isolated from solanum Nigrum L., alleviate cadmium (CD) stress response by their antioxidant potentials including sod synthesis by soda gene. Ecotoxicol. Environ. Saf. 174: 197-207.

Vaishnav A., Kumari S., Jain S., Varma A., Tuteja N., Choudhary D.K. (2016) PGPR-mediated expression of salt tolerance gene in soybean through volatiles under sodium nitroprusside. J. Basic. Microbiol. 56: 1274-1288.

Vejan P., Abdullah R., Khadiran T., Ismail S., Nasrulhaq Boyce A. (2016) Role of plant growth promoting rhizobacteria in agricultural sustainability - a review. Molecules. 21(5) DOI 10.3390/molecules21050573.

Watanabe F.S., Olsen S.R. (1965) Test of an ascorbic acid method for determining phosphorus in water and $\mathrm{NaHCO} 3$ extracts from soil 1. Soil. Sci. Soc. Am. J. 29(6): 677-678.

Yadav S., Kaushik R., Saxena A.K., Arora D.K. (2011) Diversity and phylogeny of plant growth-promoting bacilli from moderately acidic soil. J. Basic. Microbiol. 51(1): 98-106.

Zhang X., Gao J., Zhao F., Zhao Y., Li Z. (2014) Characterization of a salt-tolerant bacterium Bacillus sp. from a membrane bioreactor for saline wastewater treatment. J. Environ. Sci. (China) 26(6): 1369-1374.

Zhou N., Zhao S., Tian C.Y. (2017) Effect of halotolerant rhizobacteria isolated from halophytes on the growth of sugar beet (Beta vulgaris L.) under salt stress. FEMS. Microbiol. Lett. 364(11) DOI 10.1093/femsle/fnx091. 